\title{
The Voices of Moses: Theologies of Revelation in an Early Hasidic Circle
}

\author{
Ariel Mayse \\ Stanford University; email: amayse@stanford.edu
}

\section{Abstract}

The subject of revelation appears with striking frequency in the writings and sermons of the early Hasidic masters. Their attempts to reimagine Sinai and to redefine its spiritual significance were key to their theological project. The present article examines the theophany at Sinai as presented in the teachings of three important Hasidic leaders: Menahem Nahum of Chernobil,Ze'ev Wolf of Zhitomir, and Levi Yitshak of Barditshev, all of whom were students of Rabbi Dov Ber Friedman, the Maggid of Mezritsh. Each of the three constructed their teachings upon foundational elements of the Maggid's theology. This shared inheritance links Dov Ber's students to one another, but careful consideration of these Hasidic sources will reveal important differences in foci and ideational message. These homilies refer to revelation as an unfolding process in which the ineffable divine is continuously translated into human language, reflecting upon - and justifying the emergence of Hasidism and its theology through reimagining revelation. Such fundamental questions of language and devotion also throb at the heart of religious revivals the world over. When read critically and carefully, these Hasidic sources have much to offer scholars interested in the interface of renewal, exegesis, and revelation more broadly.

\section{Keywords:}

Jewish mysticism, Hasidism, revelation, modern Jewish thought 
The surest way of misunderstanding revelation is to take it literally, to imagine that God spoke to the prophet on a long-distance telephone.

- Abraham Joshua Heschel ${ }^{1}$

The Torah says: "And all the people saw the voices (Exod 20:15)," on which the sages commented "They saw that which is heard." They saw in Torah that which they had heard in their hearts. That is why the Torah first says "Hear, O Israel (Deut 6:4)," and only afterwards "You shall teach them to your children (Deut 11:19)."

- Barukh of Mezhbizh ${ }^{2}$

\section{Introduction}

The theophany at Sinai and the idea of revelation represent one of the core issues of Jewish theology. Beginning with the book of Deuteronomy, an early Jewish response to the Decalogue presented in Exodus, the events of Sinai were a central concern in rabbinic literature, medieval philosophy, and Kabbalah. ${ }^{3}$ Revelation has remained an issue of paramount importance to modern Jewish thinkers, as new philosophical currents as well as the findings of philology, archeology, and biblical criticism writ large, have led contemporary scholars to reconceive classical ideas of revelation. In some historical moments, Sinai was thrust into the limelight for polemical reasons. Embattled Jewish writers defended themselves against the claims made by other religions, such as Christian supercessionist readings of the Hebrew Bible or later Islamic notions of tahrif ("distortion"). Comparable debates over authority, legitimacy, and definition were sparked by the medieval Karaites' denial of the Oral Torah. But Jewish discourse on this subject has also been fueled by internal debates over the nature and content of revelation, cross-generational dialogues that cannot be essentially reduced to historical circumstance. Mystics, rationalists, and Talmudists variously explored the nature of what was given to Israel at Sinai, examining the theological — and experiential - implications of this event.

The subject of revelation appears with striking frequency in the writings and sermons of the early Hasidic masters. Their bold attempts to reimagine Sinai and to redefine its spiritual significance were key to their theological project. Though there is much in its teaching that is innovative, Hasidism is best understood as a

\footnotetext{
${ }^{1}$ Abraham Joshua Heschel, God in Search of Man: A Philosophy of Judaism (New York: Farrar, Straus and Giroux, 1955) 178.

${ }^{2}$ Botsina' de-Nehora' ha-Shalem (Lviv: 1930) 'Amarot Tehorot, 'Eke b, 20a.

${ }^{3}$ For a few key studies of this subject, see Benjamin D. Sommer, Revelation and Authority: Sinai in Jewish Scripture and Tradition (New Haven and London: Yale University Press, 2015); Abraham Joshua Heschel, Theology of Ancient Judaism (3 vols.; London and New York: Shontsin, 1962-1990) (Hebrew), translated as Heavenly Torah as Refracted Through the Generations (trans. Gordon Tucker with L. Levin; New York: Continuum, 2005); George W. Savran, Encountering the Divine: Theophany in Biblical Narrative (London and New York: T\&T Clark, 2005); and The Significance of Sinai: Traditions about Sinai and Divine Revelation in Judaism and Christianity (ed. George J. Brooke, Hindy Najman, and Loren T. Stuckenbruck; Leiden and Boston: Brill, 2008).
} 
movement of renewal that is firmly rooted in tradition. The intense communal and devotional life of Hasidism gave rise to remarkable religious creativity, and its leaders developed a vibrant mystical theology that was entirely traditional in its style of expression but surprisingly modern in some of its essential concerns. The spiritual ethos of Hasidism, which infuses traditional texts, practices, and theological concepts with devotional significance, is both daringly creative and deeply grounded in the structures and terminology of tradition. ${ }^{4}$ Early Hasidic homilies on Sinai and the nature of Torah are intimately connected to the quest for interpretative creativity that dwells at the heart of Hasidic piety.

The present article examines the theophany at Sinai as presented in the teachings of three important Hasidic leaders, all of whom were students of Rabbi Dov Ber Friedman (d. 1772). ${ }^{5}$ Dov Ber, inscribed in Hasidic memory as "the Maggid ("preacher") of Mezritsh" - or simply as "the Maggid" — was a daring theologian of great sophistication and depth. ${ }^{6}$ The Maggid was also the founder of a Hasidic school, and he and his students guided the emergence of Hasidism as a powerful socio-religious movement that has profoundly shaped the course of Jewish modernity. Each of the three students discussed herein played crucial roles in the spread of Hasidism in the decades following the Maggid's death, and all of them contributed substantially to the development of Hasidic thought. ${ }^{7}$

Our dramatis personae begins with Menahem Nahum of Chernobil (1729/301797), a popular homilist and healer who wandered as an itinerant preacher before taking an official post in Chernobil in the late $1770 \mathrm{~s} .{ }^{8}$ His Me'or 'Eynayim, a collection of sermons published shortly after his death, is widely considered a classic of early Hasidic literature. ${ }^{9}$ We turn next to the writings of Ze'ev Wolf of Zhitomir (d. 1797). Little is known about his life, but Ze'ev Wolf's sermons, published shortly after his death as 'Or ha-Me'ir, offer penetrating mystical insights as well

${ }^{4}$ See Abraham Joshua Heschel, "Hasidism as a New Approach to Torah," Moral Grandeur and Spiritual Audacity (ed. Susannah Heschel; New York: Farrar, Straus and Giroux, 1996) 33-49.

${ }^{5}$ My spelling of place names and Hasidic figures follows that of the YIVO Encyclopedia of the Jews of Eastern Europe (ed. Gershon David Hundert; New Haven and London: Yale University Press, 2010).

${ }^{6}$ Dov Ber's theology is rooted in the teachings of Yisra'el ben Eli'ezer, known as the Ba'al Shem Tov (d. 1760), but the Maggid offered an innovative approach to the nature of language and the role of words in religious experience.

${ }^{7}$ I have detailed the Maggid's theory of revelation elsewhere, and will only replicate those points that are essential for understanding the work of his students; see Evan D. Mayse, "Beyond the Letters: The Question of Language in the Teachings of Rabbi Dov Baer of Mezritch" (PhD Diss., Harvard University, 2015) 328-74.

${ }^{8}$ Menahem Nahum's son, Mordekai of Chernobil (c. 1770-1837), took on the family name Twersky. His many sons founded a many-branched network of Hasidic dynasties that endures into the present. See Gadi Sagiv, Dynasty: The Chernobyl Hasidic Dynasty and Its Place in the History of Hasidism (Jerusalem: Zalman Shazar Center, 2014) (Hebrew).

${ }^{9}$ See Arthur Green's forthcoming translation of this work. 
as fierce criticisms of sham piety and populist leadership. ${ }^{10}$ We conclude with the teachings of Levi Yitshak of Barditshev (d. 1809), ${ }^{11}$ who served as a traditional $r a \underline{b}$ (an officially-employed scholar and judicator of Jewish law) in addition to functioning as a Hasidic șaddiq. ${ }^{12}$

The theological visions articulated by these pivotal early Hasidic thinkers are united in their daring attempt to re-envision the meaning of revelation and its devotional implications. On this issue, as in a range of others, Menahem Nahum, Ze'ev Wolf, and Levi Yitshak each constructed their teachings upon foundational elements of the Maggid's theology. This shared inheritance links Dov Ber's students to one another as expressions of a shared, multi-vocal, and polychromatic spiritual ethos. ${ }^{13}$ But their teachings on the events of Sinai are by no means monolithic, and careful consideration of these Hasidic sources will reveal important differences in foci and ideational message.

The concept of revelation or even "revelation at Sinai" is a subject far beyond the scope of the current framework. My analysis will be restricted to Hasidic teachings on a particularly repercussive issue: the myth of the primeval Torah and its emergence at Sinai. This ancient tradition, which has enjoyed a rich history in Jewish thought since before the Common Era, is a cornerstone of Hasidic sermons on Sinai as God's eternal wisdom becoming uniquely expressed in the structures of language.

I will argue that these Hasidic sources refer to revelation as an unfolding process in which the ineffable divine is continuously translated into human language. They suggest quite clearly that the human voice and personal creativity enjoy a critical role in accomplishing this goal. The Hasidic sermons refer to scripture as a gateway leading to the infinite expanse of the divine mind, a determinate access point through which the scholar may witness - and become ensconced in - the ever-flowing source of continuous creativity. The text that emerged from the encounter on Sinai thus serves as the meeting ground between the human worshipper and the divine from which religious inspiration proceeds.

\footnotetext{
${ }^{10}$ See Mendel Piekarz, Hasidic Leadership (Jerusalem: Bialik Institute, 1999) 94 (Hebrew); and Arthur Green, "Around the Maggid's Table: Saddiq, Leadership and Popularization in the Circle of Dov Baer of Miedzyrzec," Zion 78 (2013) 94-95 (Hebrew).

${ }^{11}$ See the recent volume Rabbi Levi Yitzhak of Berditchev: History, Thought, Literature, and Melody (ed. Zvi Mark and Roee Horen; Rishon LeZion: Yedioth Ahronoh \& Hemed Books, 2017) (Hebrew).

${ }^{12}$ Saddiq means a "righteous person," but, building upon its significance in medieval Kabbalah, Hasidic sources use it in reference to leaders whose actions-and very being-unite the cosmos and channel blessing to their followers. See Arthur Green, "The Zaddiq as Axis Mundi in Later Judaism," Journal of the American Academy of Religion 45 (1977) 327-47.

${ }^{13}$ See also Ariel Evan Mayse, “'Moving Mezritsh': The Legacy of the Maggid and the Hasidic Community in the Land of Israel," Jewish History (forthcoming).
} 
Late eighteenth-century Hasidism was still an inchoate social movement without clearly-defined institutional structures or central leadership. ${ }^{14}$ But, even in this early stage, we can identify an ethos - and a set of core theological or devotional questions - that characterized the early Hasidic circle that gathered around Dov Ber of Mezritsh. Their homilies on the subject of Sinai should be seen as differing perspectives within what was swiftly becoming a shared theological project that conquered large swaths of Yiddish-speaking Jewry. The critical divergences in their theology are obscured if we attempt to determine a single, homogenized interpretation of revelation. But Menahem Nahum, Ze'ev Wolf, and Levi Yitshak are united in their attempt to reflect upon - and justify - the emergence of Hasidism and its theology through reimagining the thrust of revelation. ${ }^{15}$ But the fundamental questions of language and devotion, which drive forward these Hasidic sermons, also throb at the heart of religious revivals the world over. When read critically and carefully, these Hasidic sources have much to offer scholars interested in the interface of renewal, exegesis, and revelation more broadly.

\section{Silence, Word, and Text}

Classical rabbinic literature has several traditions depicting the Torah as pre-eternal or existing long before the works of creation. Many of these, like the famous description of scripture as the instrument through which God fashioned the cosmos, build upon sources from Late Antiquity that associate scripture with the sophia of Proverbs and Job. ${ }^{16}$ Such traditions were foregrounded as Jewish thinkers confronted new ideas about the nature of scripture in the medieval period, ranging from late Gnosticism to Neo-Platonism and Islamic theology. The creativity generated by the encounter with these new approaches to Torah is particularly visible in premodern Jewish mysticism.

Medieval Kabbalists viewed Sinai as a revelation of God's own self (represented by the sefirot), not just the commanding divine will. This is depicted as the emergence

${ }^{14}$ Later attempts to isolate central leadership in the formative period of Hasidism-whether under the Ba'al Shem Tov or the Maggid-are anachronistic retrojections; see Ada RapoportAlbert, "Hasidism after 1772: Structural Continuity and Change," Hasidism Reappraised (ed. Ada Rapoport-Albert; London and Portland, OR: Vallentine Mitchell, 1996) 76-140.

${ }^{15}$ See Green, "Around the Maggid's Table," 73-106.

${ }^{16}$ Bereshit Rabbah 1:1; ibid. 8:2. See also $b$. 'Eruvin 13a; Midrash Tehillim, Ps. 3; and Pirqei deRabbi Eliezer, ch. 3; Shemot Rabbah 47:9; and Ruth Zuta, ed. Buber, 1:1. See also Michael Fishbane, The Garments of Torah: Essays in Biblical Hermeneutics (Bloomington, IN: Indiana University Press, 1989) 33-48; and Azzan Yadin, Scripture as Logos: Rabbi Ishmael and the Origins of Midrash (Philadelphia, PA: University of Pennsylvania, 2004) esp. 1-77. See Barbara A. Holdrege, "The Bride of Israel: The Ontological Status of Scripture in the Rabbinic and Kabbalistic Traditions," Rethinking Scripture: Essays from a Comparative Perspective (ed. Miriam Levering; Albany: State University of New York Press, 1989) 236-39; and Harry Austryn Wolfson, Philo: Foundations of Religious Philosophy (2 vols.; Cambridge, MA: Harvard University Press, 1947) 1:115-43; and Ralph Marcus, "On Biblical Hypostases of Wisdom," Hebrew Union College Annual 23.1 (1950) 157-71. 
of the divine Word out of the recesses of mysterious inner silence. ${ }^{17}$ The thirteenthcentury Zohar describes scripture as a verdant garden overflowing with secrets. Each letter of the Torah blossoms into an untold number of new interpretations, and the exegesis of its sacred words is reckoned a mystical experience second to none.$^{18}$ Following the comments of Nahmanides in his famed introduction to his commentary on the Pentateuch, ${ }^{19}$ the Zohar's authors refer to Torah as the name of God; one passage goes so far as to identify the Torah with the blessed Holy One. ${ }^{20}$ Elsewhere the Zohar refers to scripture as taking on a linguistic "garment" at Sinai, suggesting that the language of Torah reveals - and conceals - the divine essence within. ${ }^{21}$ Medieval Kabbalists saw scripture as the nexus through which one might bridge the crevasse between the human and divine realms, for the theophany of Sinai is constantly recreated through sacred study. ${ }^{22}$ Indeed, the translation of God's wisdom into language is a continuous process rather than a single historical event. ${ }^{23}$

${ }^{17}$ See Scholem, "The Meaning of the Torah," 32-86, and the staggering array of early kabbalistic
sources mentioned in his footnotes. See also Moshe Idel, Absorbing Perfections: Kabbalah and
Interpretation (New Haven and London: Yale University Press, 2002) esp.96-110,138-39; and Elliot
Wolfson, Through a Speculum that Shines: Vision and Imagination in Medieval Jewish Mysticism
(Princeton: Princeton University Press, 1994) 345-55. See also idem, "The Mystical Significance
of Torah Study in German Pietism," Jewish Quarterly Review 84 (1993) 43-77, esp. 49; Fishman,
"The Rhineland Pietists' Sacralization of Oral Torah," Jewish Quarterly Review 96 (2006) 9-16;
and Elliot Wolfson, "Hebraic and Hellenic Conceptions of Wisdom in Sefer ha-Bahir," Poetics Today 19 (1998) 147-76.

${ }^{18}$ See Zohar 3:149a-149b. See also, inter alia, 2:95a, 98b; 3:79b. See also Melila Hellner-Eshed, A River Flows from Eden: The Language of Mystical Experience in the Zohar (trans. Nathan Wolski; Stanford, CA: Stanford University Press, 2009) esp. 155-228; Elliot Wolfson, "Beautiful Maiden Without Eyes: Peshat and Sod in Zoharic Hermeneutics," The Midrashic Imagination: Jewish Exegesis, Thought, and History (ed. Michael Fishbane; Albany, NY: State University of New York, 1993) 155-203.

${ }^{19}$ See Haviva Pedaya, Nahmanides: Cyclical Time and Holy Text (Tel Aviv: Am Oved, 2003) 120-205 (Hebrew); Moshe Halbertal, By Way of Truth: Nahmanides and the Creation of Tradition (Jerusalem: Shalom Hartman, 2006) 315-18, 331-33 (Hebrew); idem, Concealment and Revelation: Esotericism in Jewish Thought and its Philosophical Implications (trans. Jackie Feldman; Princeton: Princeton University Press, 2007) 83-92; and Elliot R. Wolfson, Open Secret: Postmessianic Messianism and the Mystical Revision of Menahem Mendel Schneerson (New York: Columbia University Press, 2009).

${ }^{20}$ Zohar 3:71; See also 2:124a; Zohar 2:60a; and Scholem, "The Meaning of Torah," 44-45.

${ }^{21}$ Zohar 3:152a; and Frank Talmage, "Apples of Gold: The Inner Meaning of Sacred Texts in Medieval Judaism," Jewish Spirituality: From the Bible Through the Middle Ages (ed. Arthur Green; New York: Crossroad, 1986) 313-55.

${ }^{22}$ This emphasis on the revelatory power of the text represents a significant development; see Scholem, "Meaning of the Torah," 41-42; Moshe Idel, "Torah: Between Presence and Representation of the Divine in Jewish Mysticism," Representation in Religion: Studies in Honor of Moshe Barasch (ed. Jan Assmann and Albert. I. Baumgarten; Leiden and Boston: Brill, 2001) 197-235; Elliot Wolfson, "Iconicity of the Text: Reification of Torah and the Idolatrous Impulse of Zoharic Kabbalah," Jewish Studies Quarterly 11 (2004) 215-42.

${ }^{23}$ See the passages from later Kabbalists Me'ir ibn Gabbai and Isaiah Horowitz cited in Gershom Scholem, "Revelation and Tradition as Religious Categories in Judaism," The Messianic Idea in 
Such Kabbalistic teachings on the emergence of Torah at Sinai nourished the theology of Dov Ber of Mezritsh, whose homilies often return to the theme of revelation. The Maggid's sermons describe scripture as the linguistic embodiment of God's infinite wisdom (called hokmah), sacred text formed as the pre-existent Torah was cast into words. The original primordial Torah, infinite and undifferentiated, could not be apprehended by the human mind. Therefore, says Dov Ber, God contracted its brilliance into a cloak of narratives and laws. ${ }^{24}$ The Torah is thus divided into different words, but also unified by the current of divine hokmah that undergirds the language of Scripture. The letters of Torah are finite vessels for God's infinite wisdom, and the discerning scholar must pierce the linguistic facade and attain the ineffable divine essence within..$^{25}$

The Maggid also intimates that Moses played an active role in drawing the Torah into language. ${ }^{26}$ Humility paired with withdrawal from all physical temptations allowed the prophet to reach into the depths of divine wisdom and shepherd the primordial scripture into words. Moses's vision of God was unique because it penetrated beyond all speech. His intimate knowledge of $\mathrm{Y}-\mathrm{H}-\mathrm{V}-\mathrm{H}$, the sacred name that is the source of all language, enabled him to summon forth God's Word from the soundless pool of infinite potential. ${ }^{27}$ This embryonic teaching on the role of Moses was developed more fully by Dov Ber's student Menahem Nahum of Chernobil, to whose teachings we shall now turn.

\section{Scripture and the Divine Mind: Menahem Nahum of Chernobil}

Menahem Nahum argues that the Torah erupted forth from the depths of the divine mind on Sinai. He refers to this abstract region of the Godhead in which language is largely inchoate as the "World of Thought" ('olam hammaȟ̌sabah), a phrase that is characteristic of the Maggid's terminology. As long as the pre-existent scripture was manifest only as the world of thought, it remained abstract and seemingly even without words. Only through revelation was this shapeless energy formed into specific language. This process of God expressing the pre-existent wisdom through a gossamer of words and letters, claims Menahem Nahum, was actively carried out by Moses. ${ }^{28}$ For this reason, the Torah often repeats: "God spoke unto

Judaism and Other Essays on Jewish Spirituality (New York: Schocken Books, 1971) 300-303; and Heschel, Heavenly Torah, 671-72.

${ }^{24}$ See Maggid Devarav le-Ya'aqov (ed. Rivka Schatz-Uffenheimer; Jerusalem: Magnes Press, 1976) no. 202, 327; and ibid., no, 134, 234; ibid., no. 132, 227-28; and no. 28, 46-47. See also 'Or Torah ha-Shalem (Brooklyn: Kehot Publication Society, 2006) no. 245, Tehillim, 28.

${ }^{25}$ Maggid Devarav le-Ya'aqov, no. 189, 292.

${ }^{26}$ Ibid., no. 132, 228; and ibid., no. 84, 146-47.

${ }^{27}$ See Gershom Scholem, "The Name of God and the Linguistic Theory of the Kabbala," Diogenes 79 (1972) 59-80; and part two in Diogenes 80 (1972) 164-94; and Eitan P. Fishbane, "The Speech of Being, the Voice of God: Phonetic Mysticism in the Kabbalah of Asher ben David and His Contemporaries," The Jewish Quarterly Review 98 (2008) 485-521.

${ }^{28}$ The biblical prophet embodies the sefirah da'at, the expansive awareness or spiritual 
Moses, telling him to speak to the Israelites"-Moses was constantly charged with translating the ineffable Torah into spoken language that could be comprehended by the people of Israel. ${ }^{29}$ The movement of scripture from concealed silence into words evidently unfolded over time rather than in a single moment of theophany. And, claims Menahem Nahum, the power of Moses's speech guided this process.

Does Menahem Nahum mean to suggest that Moses chose the words of scripture? We find some ambiguity among his various homilies. In one sermon, he argues that Moses united the revealed scripture - called the "Spoken" Torah-with the ungraspable Torah of the hidden divine mind. But, in several other teachings, Menahem Nahum throws open the possibility of Moses having taken a more creative role in formulating the revelation. Drawing on a tradition from the Maggid, Menahem Naḥum claims:

The Torah was once in the World of Thought. When the world's patriarchs studied it, they grasped it as it was in the World of Thought. . . . It was through Moses, who represents awareness ( $\left.d a^{\prime} a t\right)$, that Torah was drawn into speech, the final of the seven "days of building." ${ }^{30}$ Thus the Torah frequently says: "God spoke to Moses" or "God spoke all these words" (Exod 20:1). This means that he [Moses] drew the primordial Torah into speech and it became dressed in material garb. ${ }^{31}$

Scripture was infinitely unknowable before Sinai, when Moses cloaked the primordial Torah in a linguistic form. The claim that Torah originated in the divine "World of Thought" does not necessarily mean that it was entirely pre-linguistic. The Maggid's teachings often refer to "letters of thought" ('otiyyot hammahšabah) as essential to cognition both human and divine. ${ }^{32}$ But Menahem Nahum's statement that scripture had no verbal expression in "speech" (dibbur) before Moses is quite bold. The letters of thought are fleeting and abstract, stabilizing only as they are translated into vocalized speech. Peering into the recesses of God's mind, it seems that Moses took hold of these ethereal letters and used them in constructing a Torah expressed through words, stories, and laws.

The tension between Moses as an active participant in shaping scripture and the notion that the prophet was no more than a passive conduit for revelation is never resolved in Menahem Nahum's sermons. In one emblematic homily, he argues

consciousness often described by Menahem Nahum as the goal of religious life. See Arthur Green, "Da'at: Spiritual Awareness in a Hasidic Classic" (forthcoming).

${ }^{29}$ See also the formulation in Yeśammah Lev. (2 vols.; Jerusalem: 2002) Yoma, 2:571. See also Me'or 'Eynayim (2 vols.; Jerusalem: Yitshak Shimon Osteraykher, 2012), Bere'shit, 1:7.

${ }^{30}$ The "seven days of building" refer to the seven sefirot from hesed to malkut. See, inter alia, Zohar 1:145a.

${ }^{31}$ Me'or 'Eynayim, Shemot, 1:155. My rendering of this passage follows that of Arthur Green in his forthcoming translation of Me'or 'Eynayim, to be published by Stanford Univeristy Press in 2019. See also ibid., Shemot, 1:138; and Vayyera', 1:51.

${ }^{32}$ Mayse, "Beyond the Letters," 215-37. 
that the preexistent Torah existed in God's mind in specific words, just as it was when given at Sinai:

Our sages have taught that the Torah preceded the world by two thousand years. ${ }^{33}$ But it is known that there was no time before Creation, so how can we speak of "two thousand years"? The intention is thus: the Torah preceded the world, arising first in the mind of the Creator, just as it is written in all of its entirety, from "In the beginning" (Gen 1:1) to "before the eyes of all Israel" (Deut 34:12). ${ }^{34}$

The opening of his sermon implies that the primordial scripture was composed of letters and verses, fully identical to those revealed at Sinai. Yet Menahem Nahum goes on to suggest that the Torah was only expressed in speech when Moses cast it into words as it left the divine mind:

"Her mouth opens in wisdom (hokmah)" (Prov 31:26) - it began as the hidden wisdom, the primordial Torah. ${ }^{35}$ But "the teaching of kindness (torat hesed) is upon her tongue (ibid.) - [the sefirah] hesed was necessary for the Torah to be revealed, for it to leave [God's] Thought and to become expressed in speech. ${ }^{36}$

It became "clothed," revealed in a garment, coming to be revealed through words and letters. But, in truth, it is the very same [Torah] that once existed in the divine Will and Thought. ${ }^{37}$

The primordial Torah-God's concealed wisdom-was indeed linguistic, but it was inchoate and ungraspable until Moses translated it into a textual artifact at Sinai. This transposition was generated by God's compassionate love (hesed) for Israel, since they come to know the divine only through the words of scripture. Moses, the faithful shepherd, guided the Torah along the path from its expansive origin to its final verbal expression. But were the words of Sinai of Moses's choosing or of God's? Ambiguity on this daring question reappears consistently throughout Menahem Nahum's homilies.

Such teachings imply that the Torah was a fully-formed scripture by the time of revelation. ${ }^{38}$ But, elsewhere, Menahem Nahum argues that the entire primordial Torah was included within a single point (hokmah) and this same all-inclusive

${ }^{33}$ See Shemot Rabbah 47:9.

${ }^{34}$ Me'or 'Eynayim, Liqquțim, 2:402.

${ }^{35}$ This reading of Prov 31:26, found in the Zohar 1:145a (inter alia), is commonly cited in Hasidic teachings on revelation, including several of those below.

${ }^{36}$ Classical Kabbalah links hesed to the sefirah hokmah (both are on the right side of the sefirotic chart), but the former represents a less intense manifestation of the divine. Hasidic texts often refer to this diminution, a concealment of the divine power that paradoxically allows for a revelation of divine vitality as an expression of God's loving grace.

${ }^{37}$ Me'or 'Eynayim, Liqquțim, 2:402.

${ }^{38}$ Although some rabbinic traditions seem to assume that the entire Pentateuch was delivered to Israel, others suggest that the books of Moses were revealed over time. See b. Gittin 60a; and Heschel, Heavenly Torah, 538-51. 
point of vitality was delivered to Israel at Sinai ${ }^{39}$ He supports this claim with a rabbinic tradition that "God spoke the entire Torah in a single one of the Ten Utterances" (̌̌e'amar kol hattorah kullah bedibbur 'ehad). To my knowledge this daring formulation, which he invokes at crucial junctures in several of his sermons on revelation, does not appear as such in classical rabbinic literature. ${ }^{40}$ Menahem Nahum interprets the statement as indicating that the Torah was revealed only through the utterance of "I am Y-H-V-H your God," a radical illumination of divine self-disclosure seemingly without any further content. At Sinai, God spoke scripture into being as an endless font of sacred potential. That revealed Torah included all later developments, but lacked the words, letters, and narratives of its eventual textual form.

Here, again, we encounter Moses as the necessary intermediary. Only the prophet, argues Menahem Nahum, grasped the vital core of scripture in its abstract state. For this reason, Moses translated God's unspoken wisdom into the single formative utterance that Menahem Nahum has recast as the entire theophany of Sinai. Representing the sefirah da 'at ("awareness"), his expansive mind enables him to transpose the Torah from the primal hokmah into a voiced sound (called "qol"). ${ }^{41}$ This pre-linguistic - but audible - voice lay within the sensory threshold of the Israelites, thus revealing God's still-inchoate word.

But then Menahem Nahum links this qol to the voice described in an ancient rabbinic teaching: " "Moses spoke and God answered him in a voice' (beqol, Exod 19:19) - in the voice of Moses." ${ }^{42}$ God's silence poured through the revelatory expanse of Moses's own voice, a sublime divine utterance that reached Israel through the sound of the prophet. And yet, it is noteworthy that in this particular sermon Menahem Nahum makes no mention of any revelation through articulated speech (dibbur) at Sinai. God's wisdom thunderously echoes through the voice of the prophet, but this stage still represents only a partial disclosure of the ineffable silence of God's mind.

${ }^{39}$ Me'or 'Eynayim, Vayyera', 1:51.

${ }^{40}$ Me'or 'Eynayim, Hašmațot, 1:376. For a possible precedent, see Zohar Hadash, 38a; and RaSHI's comment on Exod 24:12. See also Mekilta, Yitro 4, and Guide II:33, and Sheney Luhot ha-Berit, $\breve{S} a \underline{b} u^{\prime}$ 'ot, Torah 'Or 45. My thanks to Arthur Green and Jordan Schuster for sharing this list of sources with me.

${ }^{41}$ Qol, consisting of an unintelligible physical sound, is abstract and unformed in comparison to articulated words. "Voice" ( $q o l)$ and "Speech" (dibbur) are thus mutually dependent. Articulated words cannot be expressed without the subterranean energy of voice, but the inchoate potential of the latter is revealed only when shaped into clearly-defined letters and words. In most Hasidic sources, as in classical Kabbalah, qol represents the sefirah tif'eret and the vav of the name Y-HV-H. See Tiqqunei Zohar, Tiqqun 21, fol. 48a; and Maggid Devarav le-Ya'aqov, no. 62, 102. See also Liqquțim Yeqarim (ed. Avraham Kahn; Jerusalem: 1973), no. 271, 89b; ibid., no. 269, 88a; and ibid., no. 241, 71b-72a. See also Sefer Yeșirah 2:6; Zohar 2:66b.

${ }^{42}$ b. Berakot 45a; and Zohar 3:7a, 264b. The plain-sense of qol in Exod 19:19 is likely "thunder." For an analysis of this rabbinic exegesis in a different Hasidic sermon, see Arthur Green, "Hasidism and Its Response to Change," Jewish History 27 (2013) 331-33. 
This account of an individual actively participating in the process of revelationhere embodied in the figure of Moses - is not restricted to the moment of Sinai. Menahem Nahum suggests that the theophany is renewed through scriptural exegesis. ${ }^{43}$ Noting that scholars interpret the legal and the narrative elements of scripture in different ways, he claims that each student draws forth new interpretations of Torah from the infinite reservoir of various potentialities given at Sinai. The sage translates the ineffable Divine into language, through the process of developing unique exegesis. From the unformed pool of potential and inspiration (hokmah), the scholar draws the idea into the concrete root of the divine mind (da'at). This stage represents the ever-rushing wellspring from which the distributaries of exegesis branch out.

This account of revelation, construed as the awakening of new ideas from the depths of God's mind, is boldly presented as continuing unabated into the present. Elsewhere Menahem Nahum offers a more guarded perspective, invoking the ancient tradition that all of the ever-broadening discourse of Torah was contained in the original revelation. ${ }^{44}$ The interpretations of later sages concretize some part of the once-abstract potential at a specific point in history. He claims that this process extended for two thousand years after Sinai, all of which are included in the "aspect of the giving of the Torah," and after this most interpretations are simply expansions of those core ideas.

This recasting of the continuous revelation of Torah through exegesis and reinterpretation shares much in common with the late medieval sources explored by Gershom Scholem. ${ }^{45}$ Menahem Nahum's original contribution lies in combining this model with his description of Moses as actively summoning the Torah from the divine mind and creatively shaping it through words. This innovation is particularly visible in his closing remarks in this sermon, where Menahem Nahum notes that some can thus command truly new exegesis of Torah because they exist beyond time. Such scholars re-awaken the power of revelation and conjure the divine silence into words once more. He applies this to the Zohar, thus explaining statements by sages that post-date Shimon bar Yohai (the work's purported author) by several generations. But I suspect that Menahem Nahum is also reflecting on the place of his teacher the Maggid - and perhaps the $\mathrm{Ba}^{\prime}$ al Shem Tov—as a creative exegete

${ }^{43}$ Me'or 'Eynayim, Vayyeșe, 1:95. See also Ariel Evan Mayse, "The Ever-Changing Path: Visions of Legal Diversity in Hasidic Literature," Conversations 23 (2015) 84-115.

${ }^{44}$ Yeśammah Lev., Šabbat, 2:510-11. On the rabbinic debate regarding which elements of the Oral Torah were revealed at Sinai, see $m$. 'Avot 1:1; b. Megillah 19b; Vayyiqra' Rabbah 22:1; Heschel, Heavenly Torah, 658-79; Ephraim E. Urbach, The Sages: Their Concepts and Beliefs (trans. Israel Abrahams; Jerusalem: Magnes Press, 1979) 286-314; Yaakov Zussman, "Torah she-Be'al Peh: Peshutah ke-Mashma 'ah," Studies in Talmud Dedicated to the Memory of Professor E. E. Urbach (ed. Yaakov Zussman and David Rozental; Jerusalem: Magnes Press, 2005) 209-384 (Hebrew); Cana Werman, "Oral Torah vs. Written Torah(s): Competing Claims to Authority," Rabbinic Perspectives: Rabbinic Literature and the Dead Sea Scrolls (ed. Steven D. Fraade, Aharon Shemesh and Ruth A. Clements; Leiden: Brill, 2006) 157-97.

${ }^{45}$ Scholem, "Revelation and Tradition," 282-303. 
whose sermons seemed to call up the Torah from the depths of the infinite silence and give it new expression in a manner befitting that specific time, place, and spiritual need.

\title{
The Inner Heart of Torah: Ze'ev Wolf of Zhitomir
}

The teachings on revelation from Ze'ev Wolf of Zhitomir, a fellow disciple of Dov Ber, engage with similar questions of exegesis, process, and creativity. In a striking homily, Ze'ev Wolf recalls the rabbinic description of the Torah as the vessel of Creation but claims that, in the days of the patriarchs, the Torah inhered in the cosmos in an abstract and undetailed form. ${ }^{46}$ In this sermon, found among the opening pages of his book, Ze'ev Wolf likens this presence of scripture to an undifferentiated sound, an expressive "voice" (qol) undergirding the cosmos as an indeterminate-though effusive-wellspring of sacred vitality rather than a specific Torah in linguistic form. The detailed particulars of scripture emerged only as the Ten Commandments were delivered by Moses. The Sinai theophany thus concretized the primordial Torah that had been previously expressed only as the latent "letters of Creation"-that is, of the formative utterances of Genesis 1 -within the physical world. ${ }^{47}$ But Ze'ev Wolf claims that this same revelatory dynamic remains accessible to contemporary scholars of Torah:

\begin{abstract}
Even now, this matter has not come to an end! The Torah is always an unarticulated "voice" (qol). From generation to generation the true șaddiqim, who walk with God's Torah, can make and create from it homiletical interpretations, fences and strictures. They do so as they see fit for the community's needs. ${ }^{48}$
\end{abstract}

The Torah continuously awaits expression, and in each generation the righteous individuals must uncover novel ways of serving God by "combining its letters and formulating" new ideas that are appropriate for that time and place. Countless books and creative exegesis have appeared over the years, says Ze'ev Wolf, because giving specific words to the unformed "voice" of Torah is a never-ending and generative quest.

Such teachings portray revelation as an ongoing process that was sparked by the theophany at Sinai but continued by scholars across generations. Ze'ev Wolf tempers this expansive vision with the notion that all subsequent creativity was concealed within the original Ten Commandments, but he hardly means that these novellae were included in the Decalogue in a specific form. Ze'ev Wolf argues that although the Ten Commandments seem rather detailed when compared to

${ }^{46}$ 'Or ha-Me'ir (2 vols.; Jerusalem: 2000) Bere'shit, 1:8. See also Seth L. Brody, “'Open to Me the Gates of Righteousness': The Pursuit of Holiness and Non-Duality in Early Hasidic Teachings," The Jewish Quarterly Review 89 (1998) 3-44.

${ }^{47}$ The link between the ten creative utterances of Gen 1 and the Ten Commandments of Exod 20 is a commonplace assertion in the writings of the Maggid's school.

48 'Or ha-Me'ir, Bere'shit, 1:8. 
the primordial Torah, the initial theophany at Sinai was no more than a preverbal "sound" (qol) in contrast to all the "words" (dibburim) - the new ideas, concepts, and practice - drawn forth by later sages. Flexing the boundaries of temporality, this subsequent exegesis continues the original moment of revelation: "Therefore we bless God as, 'the One who gives the Torah,' teaching that the blessed Holy One is still giving the Torah, from time immemorial, just as He did at the holy assembly on Sinai." 49 The power of Oral Torah and creative exegesis lies in continuously ushering the primordial Torah into language anew.

Thus far, Ze'ev Wolf's theology of revelation seems to afford little uniqueness to Moses - nor does it single out the actual theophany at Sinai as a singular moment in which God unveiled the hidden depths of the divine mind. This picture was made more complicated, however, by a sermon on the following verse: "Y-H-V-H spoke to Moses face to face, as one speaks to his friend" (Exod 33:11). Ze'ev Wolf opens by noting that if God had bestowed the Torah as it exists "in its place" - in the abstract divine realms - the scripture would have remained incomprehensible to the human intellect. ${ }^{50}$ Therefore, God diminished the intensity of this subtle and sublime Torah by focusing its light and garbing it (leșamșem ulehalbiš) within the proverbial "seventy faces" of scripture. This restraint allowed Israel to encounter the divine through the words of scripture at Sinai, but it also makes it possible for all later exegesis to unfold. This process of revelation as "constriction" (șimșum) likely inherited from the Maggid - translated the pre-verbal Torah into language and, thus, within the threshold of human sensitivity.

These many "faces" of scripture (panim), the linguistic aspects of Torah that simultaneously reveal and conceal, represent the "face to face" (panim 'el panim) encounter mentioned in the biblical verse; they are the nested layers of diminishing revelation through which scripture became accessible. These strata were, according to Ze'ev Wolf, communicated to Moses in a moment of intimate communion at Sinai. The Torah was embodied in "face" after "face" until it became a collection of stories (sippurey ma 'aśiyyot) describing the trials and tribulations of a human community. But, says Ze'ev Wolf, a perceptive individual ('iš maśkil) attuned to the deeper layers of Torah will strip away this corporeal garb and, thus, restore Torah to its pristine spiritual form.

The identity of this person is, for our Hasidic master, no surprise. He is the saddiq, reenacting the role of Moses by reaching toward the pulsing inner heart of the Torah (penimiyyut) that is concealed within - and disclosed through-its exterior narrative "face." Though he may be tempted to do so, Ze'ev Wolf stresses that this graced individual cannot remain in silent communion with this ineffable core of Torah. ${ }^{51}$ The saddiq must depart from the inner world of contemplation, and,

49' Or ha-Me'ir, Bere'shit, 1:8.

50 'Or ha-Me'ir, Tiśśs', 1:182-84.

${ }^{51} \mathrm{Ze}$ 'ev Wolf often returns to the issue of the șaddiq embracing language for the sake of others. This struggle with the beckoning of meditative silence distinguishes him from Menahem Nahum 
imitating God at Sinai, the earthly teacher must "speak Torah" by communicating its message through a linguistic medium that can be grasped by his listeners. ${ }^{52}$

As scholars reinterpret the letters of scripture by "recombining" them into the novel interpretations of the unfolding Oral Torah, the supernal Torah nears revelation in all of its illuminated clarity and fullness. This, says Ze'ev Wolf, is the reason that it was once prohibited to write down the Oral Torah: such interpretations are continuously evolving, reflecting the ever-changing manner in which human exegetes engage with scripture..$^{53}$ Indeed, this dynamic aspect of Torah could not have been revealed at Sinai, because the very notion of free choice in divine service and interpretation of scripture depends on the possibility of one being able "to grasp, of his own volition, these combinations of letters of the Torah that await him" (mamtinin 'alav)..$^{54}$

Like the teachings on Moses's power to summon forth the Torah developed by Menahem Nahum of Chernobil, several of Ze'ev Wolf's sermons highlight the unique place of the prophet. He notes that Moses grasped the sublime mysteries of divine wisdom without any need for translation, gazing upon the illuminated Torah and presumably grasping the radiance of scripture beyond the cloak of language:

"Y-H-V-H said to Moses, 'Behold I will come to you in a thick cloud, so that the people will listen when I speak to you.'” (Exod 19:9).

Moses our Teacher had so purified and clarified his own bodily self that God could have shown him the power of Torah with full clarity, without any "garbing" or diminution of intensity. ...

But if that is the case, why did the blessed Holy One dress up the brilliant light of Torah in stories, until it became something like tales one person would tell another? ${ }^{55}$

Though Ze'ev Wolf does not formulate this point explicitly, his description of the primordial Torah as undifferentiated brilliance suggests that the pre-existent scripture lacked the mantle of words. He therefore asks why scripture needed to be invested in stories, laws, and narratives at Sinai; surely it could have been conveyed to the faithful prophet without resorting to words. Ze'ev Wolf continues:

of Chernobil, whose teachings evince none of this reticence toward the spoken word. See, for example, the text translated in Arthur Green, Speaking Torah: Spiritual Teachings from Around the Maggid's Table, with Ebn Leader, Ariel Evan Mayse and Or N. Rose (2 vols; Woodstock, VT: Jewish Lights, 2013) 1:125.

${ }^{52}$ On the phrase "speaking Torah" and the Hasidic sermon as a moment akin to revelation, see Arthur Green, "The Hasidic Homily: Mystical Performance and Hermeneutical Process," in As a Perennial Spring: A Festschrift Honoring Rabbi Dr. Norman Lamm (ed. Bentsi Cohen; New York: Downhill Publishing LLC, 2013) 241-42.

${ }_{53}{ }^{\prime}$ Or ha-Me'ir, Tišśs', 1:184.

${ }^{54}$ Ibid.

${ }_{55}$ 'Or ha-Me'ir, Šabu'ot, 2:11-13; based on the translation in Green, et al., Speaking Torah, 2:216-17. 
"Her mouth opens in wisdom (hokmah), but the teaching of kindness (torat hesed) is upon her tongue" (Prov 31:26).

Sometimes a marvelous bit of wisdom falls into an intelligent person's mind, something that contains a real insight into understanding God. But when he tries to share that thought with another person, you are unable to reveal the wisdom that lies buried deep within your own heart. It would just be too subtle for them to understand.

You therefore have to dress it up as a comment on a biblical verse or some saying of the sages. For this purpose, one can employ any of the four ways of reading Scripture, the obvious, the allegorical, the homiletical, or the esoteric.

Those people in any case will not be able to grasp the depth of your thoughts, however they are garbed. They therefore pay attention only to the garments themselves. "How well this one preaches! How nicely this one speaks!" They are just too unaware to pay attention to that wonderful inner wisdom and the good counsel for serving God that they could be finding in the multiple levels of his preaching. ${ }^{56}$

Ze'ev Wolf illustrates his theology of revelation with the poignant image of a human preacher struggling to convey a feeling of religious inspiration or spiritual insight to his community. The homilist is pressured by a paradox and strains the power of language in both directions. Without words, the preacher cannot share the idea or experience with others, but expressing it in language diminishes - and perhaps even denatures - the intensity of the original insight. This tension is further exacerbated by the fact that most listeners will pay mind only to the felicity of the rhetoric, missing the sublime wisdom held within the letters.

Language may tarnish the luster of an idea as it arose in the homilist's mind, but words are needed to convey such insights. The preacher's words and parables are a compromise, but they also focus the intensity of his wisdom into a conduit that may be grasped by others. Such, says Ze'ev Wolf of Zhitomir, was the process of revelation:

Our holy Torah is itself in the same situation. Its words as "open" in their own setting indeed shine a high and lofty light, but one so subtle that "thought cannot grasp it at all." ${ }^{57}$ But when the time came for the [Ten] words (i.e., the Decalogue) to be revealed in the holy event at Sinai, they had to be garbed in the outer meanings and narrative tales of Torah.

"Her mouth" (Prov 31:26) refers to the [origins of] Torah, which "opens in wisdom" (ibid.) before it was revealed in speech. Its illumination came only through marvelous wisdom and the deepest of secrets. But "the teaching of kindness is upon her tongue"-when it entered the realm of language, so that the Commandments might be uttered on Sinai, it was a Torah of beauty and pleasure. ${ }^{58}$

${ }^{56}$ Green, et al., Speaking Torah, 2:217.

${ }^{57}$ See Tiqqunei Zohar, Haqdamah 'Aheret, 17a.

${ }^{58}$ Green, et al., Speaking Torah, 2:217-18 
Ze'ev Wolf's reading of Prov 31:26 is very nearly the polar opposite of Menahem Nahum's interpretation of the same verse. Whereas the latter underscores revelation as an act of kindness and compassion (hesed), Ze'ev Wolf emphasizes that the aesthetic beauty of the language of Torah occludes the ineffable secrets that once radiated from its core. Most people require such translation into words in order to grasp these mysteries, but Ze'ev Wolf enjoins his listener-or reader - to remember that the linguistic clouds of revelation may conceal more than they disclose.

That is why Scripture tells us: "Behold I will come to you in a thick cloud." The whole Torah, with its point of departure of the word 'anokhi ("I am," Exod 20:2), will come to you . . . clothed and with reduced intensity, all for the sake of this holy people in its entirety, since they are not prepared to receive Torah in its clear state.

"So that the people will listen when I speak to you." They will hear and understand the Ten Commandments, each in accord with their own levels of personal purity and the ability of each soul to hold fast to the letters of Torah. ${ }^{59}$

God's pristine wisdom, once beyond compare just as it was beyond language, was revealed through the matrix of language as a gift to Israel and their future generations. Like an opaque cloud, the words of scripture diminish one's vision of the Torah's primeval light, but they also enable the reader to withstand the intensity of its inner heart. Revelation thus enabled each worshipper to encounter the sacred writ and, through it, to grasp a unique part of the unceasingly divine voice that thunders across the generations. Ze'ev Wolf emphasis that, just as every individual listening to a homily will glean an exegetical message that speaks to his own personal situation, each reader of the Torah must attain the inner essence of scripture in a manner that befits his level of spiritual refinement.

Menahem Nahum of Chernobil and Ze'ev Wolf of Zhitomir put forward complementary visions of revelation as the birth of Torah - and God - in language. Both Hasidic thinkers highlight the question of human agency in the formation of scripture as well as its subsequent interpretation. It is interesting to note that these two figures held the same occupation: they were communal preachers (maggidim) whose livelihood and intellectual careers required them to offer creative and inspiring homilies grounded in canonical texts. Ze'ev Wolf's sermon offers some personal words on this subject, tracing the parallel between God and the human preacher. Both, he says, take sublime ideas and "garb" them in words that may be understood by their listeners. The linguistic form of the Torah, perhaps indeed shaped by human creativity, has been imbued with this illumination. But the communal maggid, and perhaps the Hasidic saddiq more broadly, must weave exegetical garments of words and parables through which to communicate his sublime insight. This linguistic edifice, drawn together from threads of scriptural or rabbinic passages, rests firmly upon an interior foundation stone: the preacher's

${ }^{59}$ Ibid. 
spiritual awakening, an experience beyond words that can only be revealed through language.

\section{Interpretation and Illumination: Levi Yitshak of Barditshev}

These entwined threads of creative exegesis, personal illumination, and divine revelation lead us directly to the teachings of Rabbi Levi Yitshak of Barditshev, our third and final Hasidic master. His sermons often underscore Israel's experience at Sinai, frequently granting more attention to the devotional implications of the theophany than to its ideational core. At Sinai, says Levi Yitshak, God's essential majesty was revealed.$^{60}$ But, lest Israel be overcome by the intensity of this vision, God addressed the community through language so that the theophany could be apprehended by the entire Jewish people. ${ }^{61}$ This compassionate act of divine selfdiminishment (simșum) into words enabled Israel to grasp the depths of Torah. ${ }^{62}$ Mirroring Ze'ev Wolf's clever exegesis of the image of the cloud (Exod 19:9), Levi Yitshak interprets the liturgical phrase, "You revealed Your glory in a cloud,"63 as teaching that God-and Scripture-were expressed at Sinai in an intentionally occluded form. ${ }^{64}$

The diminishment of God's glory did not, however, threaten the centrality of the Sinai moment. In fact, Levi Yitshak emphasizes that this moment of revelation was so exalted that all Israel attained the very highest level of prophecy. He strikingly suggests that the phrase "we will do and we will understand" (na 'aseh venišma", Exod 24:7), a critical watchword in Jewish thought and theology, was actually uttered by šekinah speaking from the throat of each Israelite. ${ }^{65}$ This expansive vision of revelation is quite remarkable, suggesting as it does that the entire people achieved a spiritual rung restricted by most earlier texts to Moses alone. ${ }^{66}$

Levi Yitshak's emphasis on the people - and God's concern for them-is an unmistakable thrust that cuts across his homilies. The focus on all Israel - and only

${ }^{60}$ See Qedushat Levi (2 vols.; ed. Michael Derbaremdiger; Brooklyn: Mekhon Kedushat Levi, 2007), Va'era', 1:156; and also, ibid., Vayyigash, 1:116.

${ }^{61}$ Based on the translation in Green, et al., Speaking Torah, 1:202-203.

${ }^{62}$ Qedushat Levi, Yitro, 1:205.

${ }^{63}$ From the Rosh ha-Shanah liturgy.

${ }^{64}$ See Qedushat Levi, Yitro, 1:199

${ }^{65}$ Levi Yitshak interprets the verse, "Moses returned the words of the people to God" (Exod 19:8) to mean that Moses attributed Israel's words to none other than God; šekinah, the ultimate source of their inspiration, was speaking through them. See Qedushat Levi, Yitro, 1:202.

${ }^{66}$ See Zohar 2:82a-b; Zohar Hadash, fol. 77a. See also Zohar 2:93b-94a; 2:156b; 3:152a. See Wolfson, "Hermeneutics of Visionary Experience," 379. Building on an ambiguity in Exod 19:19 (qol may be translated as "voice" or "thunder"), the Zohar claims that šekinah itself spoke from Moses' throat on Sinai. See Zohar 3:7a, 265a, and especially 232a (R. M.), and see also b. Berakhot 45a. This teaching is often summoned up in Hasidic descriptions of the șaddiq's sermon as a moment of divine revelation. See Heschel, Heavenly Torah, 530-31; and Green, "Hasidic Homily," 261-62 n. 21. 
Israe ${ }^{67}$-receiving the revelation, rather than Moses receiving the Torah and passing it down to them on a lower level, recalls the medieval debate between Yehudah Halevi and Maimonides. ${ }^{68}$ The national, collective and direct revelation is favored by Levi Yitshak, whereas reverberations of the elitist (but perhaps potentially more universal) spiritual experience beheld by the perfectly-trained prophet emerge in the teachings for Menahem Nahum of Chernobil and Ze'ev Wolf of Zhitomir. ${ }^{69}$ And yet, the distinction between Moses and the Israelites is not fully eclipsed in Levi Yitshak's teachings. He imagines the prophet berating Israel for lacking the courage to hear the Ten Commandments directly from God. ${ }^{70}$ This point thus stands in obvious tension with Levi Yitshak's description of šekinah speaking through all Israel-in this case, only Moses embodies the revelatory divine quality and "speaks" the ineffable Torah into being.

The question of human agency as expressed in exegetical creativity seems to have concerned Levi Yitshak more than the issue of the primordial Torah and its relationship to human language. In exploring the boundaries of interpretive authority, Levi Yitshak links the theophany at Sinai to a cornerstone of his theology: the spiritual activism of the saddiq. Before the Torah was given, argues Levi Yitshak, all divine decrees were fulfilled just as uttered; human beings could neither transform nor overturn God's edicts. But something totally new was generated (nithaddeš) through revelation, since, after Sinai, the cosmos is conducted in accord with the wishes and behavior of Israel. God surrendered a measure of control, granting Israel the authority to overturn strict divine decrees into bounty

${ }^{67}$ Levi Yitshak frequently emphasizes the exclusion of non-Jews from revelation. This may be the inverse of the unflagging love for Israel evidenced in his work, but it is also linked to Levi Yitshak's understanding of Sinai as the moment in which God relinquished interpretive control of Torah - and indeed, command of the physical worlds - to Israel alone. See Qedushat Levi, Ve-Zot ha-Berakhah, 1:434, interpreting b. Shabbat 89a; see also b. Avodah Zarah 2b; and Qedushat Levi, Šabu'ot, 1:319-20. See also ibid., Ha'azinu, 2:432; and Liqquțim, 483.

${ }^{68}$ Kuzari 1:87-91, and see also 1:9 and 1:79. See Diana Lobel, Between Mysticism and Philosophy: Sufi Language of Religious Experience in Juda Ha-Levi's Kuzari (Albany, NY: State University of New York Press, 2000) 35-44, 144-45; and Warren Zev Harvey, "Judah Halevi's Synthetic Theory of Prophecy and a Note on the Zohar," in Many Voices: Rivka Shatz-Uffenheimer Memorial Volume (ed. Rachel Elior and Joseph Dan; Jerusalem Studies in Jewish Thought 13; Jerusalem: Mandel Institute of Jewish Studies, 1996) 141-56 (Hebrew). See Guide 2:33; and 1:54, and see also Mishneh Torah, Hilkhot Yesodei ha-Torah, 8:1-2. See also Alfred Ivry, "Revelation, Reason and Authority in Maimonides' Guide of the Perplexed," in Reason and Revelation as Authority in Judaism (ed. Norbert M. Samuelson; Melrose Park, PA: Academy for Jewish Philosophy, 1981) 1-33.

${ }^{69}$ For an alternative reading of Levi Yitshak's universalism and its implications for revelation, see Shaul Magid, Hasidism Incarnate: Hasidism, Christianity, and the Construction of Modern Judaism (Stanford, CA: Stanford University Press, 2015) 62-65 and 76-79; and see also Or N. Rose, "Protest or Discernment? Divine Limitation \& Mystical Activism in the Qedushat Levi," BeRon Yahad: Studies in Jewish Thought and Theology in Honor of Nehemia Polen (ed. Ariel Evan Mayse and Arthur Green; Boston: Academic Studies Press, forthcoming 2019).

${ }^{70}$ Qedushat Levi, Va'ethannan, 1:375, 378. See also ibid., Ha'azinu, 1:432, where Levi Yitshak makes a similar point about Moses's prophecy and the song of Deut 32. 
and blessing. ${ }^{71}$ And, says Levi Yitshak, this love for Israel and the resulting divine vulnerability shaped the very form of the Torah:

"You have yourselves seen that from amid the heavens I spoke with you" (Exod 20:19-20). The blessed One conducts the world in accord with the splendor of Israel (betif'eret yiśra'el), just as they wish. ... This is the reason [that Revelation] began with "I am."

In truth, the Torah has many other and greater combinations [of letters], but, due to love for Israel, it was given in a form that the lower worlds could withstand. The blessed Holy One acts in accord with their will, [giving the Torah] in a manner that they could endure. Thus "from amid the heavens I spoke with you" - I have spoken the Torah in accord with your intellect. ${ }^{72}$

The primordial Torah has been revealed together with its sublime brilliance that would have overpowered Israel. God's love for the Jewish people led to bestowing them with an attainable Torah composed of words and letters, attenuating the divine light through the lens of language. This act of divine affection and kindness thus shaped the form of scripture, simultaneously empowering Israel to shape-and even overturn-God's will.

Israel does so, writes Levi Yitshak, through textual exegesis. He daringly extends his interpretation of the reworked Talmudic dictum of, "the blessed Holy One decrees something and the saddiq annuls it," to the Torah itself, suggesting that the meaning of scripture may be summoned forth and utterly transformed through human exegesis. ${ }^{73}$ Indeed, Levi Yitshak makes clear that scholars must ensure that scripture, the divine decree-cum-text, is interpreted correctly through the process of homiletics.

This notion of absolute exegetical freedom being given on Sinai appears frequently in Levi Yitshak's homilies, and is among the most important elements of his rereading of revelation. ${ }^{74}$ But even more striking is his extension of this activist posture to reinterpreting halakhah, a key component of the Oral Torah, which Levi Yitshak claims must be reformulated in each and every generation. ${ }^{75}$ Invoking a Talmudic tradition, he argues that Israel must believe in a two-fold Torah given by a single Shepherd: ${ }^{76}$

${ }^{71}$ See Qedushat Levi, Liqqutim, 2:458, which refers to the famous story of the "Oven of Akhnai" in $b . B a b a$ Meși a $59 \mathrm{~b}$.

${ }^{72}$ Qedushat Levi, Yitro, 1:212-13.

${ }^{73}$ See b. Mo'ed Qatan 16b; Green, "Hasidism and Its Response to Change," 332-33; and idem, "Teachings of the Hasidic Masters," Back to the Sources: Reading the Classic Jewish Texts (New York: Simon and Schuster, 1984) 374-86.

${ }^{74}$ For example, see Qedushat Levi, Va'ethannan, 1:379-380. See also Moshe Idel, "White Letters: From Levi Isaac of Berditchev's Views to Postmodern Hermeneutics," Modern Judaism 26 (2006) 169-92.

${ }^{75}$ See Qedushat Levi, Liqquțim, 2:463-64; and Ariel Evan Mayse, "The Ever-Changing Path: Visions of Legal Diversity in Hasidic Literature," Conversations 23 (2015) 84-115.

${ }^{76}$ Qedushat Levi, Yitro, 1:206-207. 
[God] handed the Written Torah to us through Moses, His faithful servant, engraved on the tablets in black fire on white fire. The Oral Torah was given to Moses in the form of commentary, including "what every faithful student was ever to find anew." 77

This is to say that the Oral Torah was given so that whatever the saddiqim of a particular generation were to say would indeed come to pass. This is the great power that the blessed Creator gave to us, out of His love for His chosen people Israel. According to their will, as derived from the Torah, all the worlds would be conducted. Of this the sages said: "God issues a decree, but the saddiq cancels it." ${ }^{\prime \prime}$

The Written Torah, the text of which is described as unchanging and immutable, was given as the tablets at Sinai. But the Oral Torah, delivered to Moses as a dynamic exegetical mandate that complements the static divine writ, is contentiously expressed through the new interpretations voiced by saddiqim in each and every generation. God relinquished this power to Israel out of love, renouncing a measure of control and enabling the leaders of the Jewish people to conduct the cosmos in accord with their needs and desires. ${ }^{79}$

Gesturing to the boldness of this teaching, Levi Yitshak notes that even Israel was surprised by the fact that the Oral Torah changes in each generation. This astonishment subsided, however, as they realized that the new ideas were once hidden within the Written Torah given at Sinai; innovative commentary is simply revealed by later saddiqim, whose exegesis continues the unfolding of God's will sparked in the theophany at Sinai. ${ }^{80}$ The infinite sweep of divine wisdom entered into language on Sinai in the moment of revelation and became known to Israel through the sacred text. In doing so, however, God relinquished control of the cosmos to the human community of șaddiqim and their mystical exegesis.

This remarkable interpretive freedom in reading and reinterpreting scripture is possible because its sacred words, conduits for the divine presence, hold an endless multiplicity of meaning. Indeed, says Levi Yitshak, the rabbis taught that the entire Torah was included in the first two Commandments, since every word of scripture is a vessel that contains infinity. ${ }^{81}$ But the sacral quality of the words of Torah is linked to a broader conception of language in early Hasidism, one in which all words may become vehicles for divine revelation. Words are described as a divine gift, and the faculty of speech is nothing less than an element of God dwelling within the human being and revealed through language. This means that the words of a

${ }^{77}$ See, inter alia, y. Pe'ah 2:4.

${ }^{78}$ Qedushat Levi, Yitro, 1:206, following the translation in Green, "Hasidism and its Response to Change," 332.

${ }^{79}$ Rose, "Protest or Discernment," deftly links God's willing abandonment of exegetical control to Levi Yitshak's theory of șimșum, one that he inherited from the Maggid but further developed in light his own theological goals.

${ }^{80}$ Qedushat Levi, Purim, 1:237-38.

${ }^{81}$ Ibid., Bešallah, 1:197-98. 
worshipper, scholar, or teacher are illuminated by the same polysemous quality that inheres in God's speech. The divine voice of Sinai, as it were, continuously echoes within the words of the human being. ${ }^{82}$

\section{Conclusion}

The sermons of Menahem Naḥum, Ze'ev Wolf, and Levi Yitsḥak have reimagined revelation as a sustained process in which God's wisdom constantly emerges from the concealed divine mind. Their theological teachings depict this continuous moment of translation, from godly silence into words that are at once human and divine, in mythic rather than historical terms. All three of these Hasidic thinkers broach the question of agency and interpretive authority, underscoring the seemingly-unlimited power of human exegetes to shape-and reshape-the biblical text for their particular community.

Why was revelation so important for this circle of mystics, and what do the teachings of Menahem Nahum, Ze'ev Wolf, and Levi Yitshak on this subject tell us about the theology of this early Hasidic school? For Dov Ber and his students, the issue of revelation is directly linked to the legitimacy of Hasidism, emerging in these early years as an innovative socio-theological movement calling for-and grounded in - new interpretations of sacred texts. ${ }^{83}$ The similarity between the theological positions staked out on this issue by these three Hasidic masters is noteworthy. Unlike the dissent found among the Maggid's school regarding issues like models of leadership, there is much consistency between Maggid and his various students in rethinking the idea of revelation. Revelation, understood as the translation of divine wisdom into the cloak of human language, is directly relevant to the new spiritual values of early Hasidism.

The emerging Hasidic institution of the saddiq may have allowed for this daring reading of Moses as a personal font of revelation. The exemplar of the prophet is most clearly articulated in the teachings of Menahem Nahum, but a similar vision of human engagement with the words of scripture emerges from the homilies of the other two Hasidic thinkers. Moses translated the Torah into a language that future human generations could interpret and expand; he served as a funnel point, where divine infinity was narrowed down, only to expand again in the infinite reinterpretations of the sacred words of Torah. That the saddiqim have taken the place of scholars in this ongoing process of revelation is one of the critical novum of Hasidism; it is also the most prominent theme that cuts across Levi Yitshak's

\footnotetext{
${ }^{82}$ See also Beit 'Aharon (Brody: 1875) 62a; and the translation in Green, et al., Speaking Torah, 1:201-202. See also Divrat Shlomo (Jerusalem: Ya'akov Yitshak Weiss, 2011) Yitro, 170. See also 'Or Torah, no. 92, 128; and 'Or ha-Me'ir, Yitro, 1:141

${ }^{83}$ See Green, "The Hasidic Homily," 237-65; Nehemia Polen, "Hasidic Derashah as Illuminated Exegesis," in The Value of the Particular: Lessons from Judaism and the Modern Jewish Experience. Festschrift for Steven T. Katz on the Occasion of His Seventieth Birthday (ed. Michael Zank and Ingrid Anderson; Leiden and Boston, MA: Brill, 2015) 55-70.
} 
entire oeuvre. ${ }^{84}$ But these Hasidic sources also seek to map the dynamic of the ever-unfolding Torah back onto the original theophany itself, thus justifying the appearance of the saddiq as an intermediary between the divine mind and the human community, akin to Moses. And, in what is perhaps the most radical implication of these sermons, we hear unmistakable suggestions that, even at Sinai, the Torah was garbed in the mantle of language through human creativity.

Many of those gathered in Mezritsh describe Torah study - and the delivery of Hasidic sermons - as recalling the moment in which God first entered language. For these thinkers, the quest to discover the divine presence within the words of scripture was linked to the creative journey of shepherding new ideas from ineffable silence and into language. These texts thus bespeak a type of mystical empowerment, manifest quite clearly in Levi Yitshak's demand that Hasidic leaders constantly reinterpret the law and overturn heavenly decrees. I suspect such teachings may have been addressed to those watching the burgeoning Hasidic movement, justifying its bold social and theological innovations with creative textual exegesis rooted in Sinai.

The boundaries of the present comparison of early Hasidic teachings on revelation has been defined by the exigencies of space, but such work could be fruitfully expanded in several directions. We might, for example, wish to include other critical figures in the Maggid's circle, such as the notable Shneur Zalman of Liady (1745-1812). An accomplished scholar of rabbinic law, he emerged as a creative and highly influential Hasidic leader and theologian - with a flourishing Hasidic court - in the final decades of the eighteenth century. ${ }^{85}$ Shneur Zalman's highly-intellectualized reading of Sinai as paving the way for cerebral communion with the divine both complements and challenges other voices in the Maggid's circle. ${ }^{86}$ Future research will be needed to demonstrate the variety of opinions regarding revelation and the various orbital issues of devotion that were expressed among the Maggid's school and beyond. ${ }^{87}$

\footnotetext{
${ }^{84}$ Arthur Green, "Typologies of Leadership and the Hasidic Zaddiq," Jewish Spirituality: From the Sixteenth-Century to the Present (ed. Arthur Green; New York: Crossroad, 1989) 127-56.

${ }^{85}$ See Immanuel Etkes, Rabbi Shneur Zalman of Liady: The Origins of Chabad Hasidism (trans. Jeffrey M. Green; Waltham, MA: Brandeis University Press, 2015); and Rachel Elior, The Paradoxical Ascent to God: The Kabbalistic Theosophy of Habad Hasidism (trans. Jeffrey M. Green; Albany, NY: State University of New York Press, 1993).

${ }^{86}$ Liqqutei Torah (Brooklyn NY: Kehot Publication Society, 2006) 12c-13b. See also Liqqutei 'Amarim-Tanya, Sefer shel Beinonim (Brooklyn, NY: Kehot Publication Society, 1998) ch. 47, 67b; Torah 'Or (Brooklyn, NY: Kehot Publication Society, 2008), Megillat 'Ester, 91b and fol. 93b; ibid., Yitro, 70d-71c.

${ }^{87}$ Hasidic thinkers outside of the Maggid's immediate circle, such as Pinhas of Korets, Moshe Hayim Efrayim of Sudilkov, Nahmman of Bratslav, Yehiel Mikhl of Zlotshev, and Yitshak of Radziwiłł, were also deeply concerned with revelation.
} 
We might also link these teachings to Hasidic meditations on the rabbinic legends of biblical figures who kept the laws of the Torah before Sinai. ${ }^{88}$ Such sermons frequently use this curious bit of rabbinic lore to explore the spiritual power of the commandments and to probe questions of religious authority. ${ }^{89}$ Their divergent answers as to why revelation was necessary in light of this tradition are quite instructive. For example, Dov Ber argues that the verbal garment of Torah was shaped by the deeds of the patriarchs, dovetailing with the account of Moses's actively creative role in the formation of Torah found in the sermons examined above..$^{90}$

In drawing to a close, I hope that the significance of this reading of the Hasidic sources - and their philosophical and devotional implications - extends beyond our understanding of a certain kind of theological turn in the late eighteenth or early nineteenth century. At the outset of this paper, I suggested that we would do well to put these Hasidic teachings in dialogue with their rabbinic and medieval Jewish forbearers. This argument could also be extended in the opposite direction: looking to the Hasidic sources in order to enrich our understanding of contemporary theories of revelation.

Modern Jewish theologians have long struggled to integrate the findings of academic scholarship with the conceptions of Sinai in traditional sources. ${ }^{91}$ Some have noted the relevance of Hasidic and Kabbalistic sources for developing contemporary theories of revelation. Ahron Marcus, ${ }^{92}$ Martin Buber, Franz

${ }^{88}$ See $b$. Yoma 28b, and parallels; Arthur Green, Devotion and Commandment: The Faith of Abraham in the Hasidic Imagination (Cincinnati, OH: Hebrew Union College Press, 1989); and Jerome Gellman, "The Figure of Abraham in Hasidic Literature," Harvard Theological Review 91 (1998) 279-300.

${ }^{89}$ See Maoz Kahana and Ariel Evan Mayse, "Hasidic Halakhah: Reappraising the Interface of Spirit and Law," AJS Review 41 (2017) 375-408.

${ }^{90}$ Maggid Devarav le-Ya'aqov, no. 134, 234. See also Avivah Gottlieb Zornberg, Bewilderments: Reflections on the Book of Numbers (New York: Schocken Books, 2015) 263-85.

${ }^{91}$ See Louis Jacobs, Principles of the Jewish Faith (London: Valentine Mitchell, 1964); David Weiss Halivni, Revelation Restored: Divine Writ and Critical Responses (Boulder, CO: Westview Press, 1997); Sommer, Revelation and Authority; Marc B. Shapiro, The Limits of Orthodox Theology (Oxford: The Littman Library of Jewish Civilization, 2004); and In the Eyes of God and Man: Biblical Criticism and the Person of Faith (ed. Yehudah Brandes, Tova Ganzel and Chayuta Deutsch; Jerusalem: Beit Morasha, 2015) (Hebrew).

${ }^{92}$ See Ahron Marcus, Der Chassidismus: Eine Kulturgeschichtliche Studie (Pleschen: Jeschurun, 1901) 239. 
Rosenzweig, Gershom Scholem, ${ }^{93}$ Abraham Joshua Heschel, ${ }^{44}$ Arthur Green, ${ }^{95}$ Tamar Ross, ${ }^{96}$ as well as Benjamin Sommer and Yehudah Gellman, ${ }^{97}$ have pointed toward the flexible understanding of Sinai in Jewish mystical literature. The Hasidic sources explored above may not have been known to all modern Jewish thinkers, though repercussive echoes of the core Hasidic teaching on revelationon transposing the ineffable divine into sacral word and the impassioned love of exegesis - reverberate in the writings of many twentieth-century Jewish thinkers. ${ }^{98}$

The Hasidic sources detailed in the present study illustrate the close-knit imbrication of spiritual renewal, scriptural interpretation, and revelation in Hasidic theology. More than a window into a historical debate, these sermons address fundamental questions that grip all communities in which textual exegesis, theological creativity, and personal religious experience are first-order values. ${ }^{99}$ The Hasidic homilies deserve careful consideration as a sophisticated and nuanced intellectual wellspring, one with much to offer contemporary theological

${ }^{93}$ On Buber, Scholem and Rosenzweig, see Rivka Horwitz, "Revelation and the Bible according to Twentieth-Century Jewish Philosophy," in Jewish Spirituality: From the Sixteenth-Century to the Present (ed. Arthur Green; New York: Crossroad, 1989) 346-370; see also Gershom Scholem, "Religious Authority and Mysticism," in On the Kabbalah and Its Symbolism, trans. Ralph Manheim (New York: Schocken Books: 1996) 29-31.

94 The goal of Heschel's Heavenly Torah was to demonstrate the variety of opinions in classical rabbinic sources, but he refers to mystical sources (implicitly and explicitly) throughout; see esp. Heschel, Heavenly Torah, 658-700.

95 See Arthur Green, Seek My Face: A Jewish Mystical Theology (Woodstock, VT: Jewish Lights, 2003) 97-144; idem, Radical Judaism: Rethinking God and Tradition (New Haven: Yale University Press, 2010) 79-119.

${ }^{96}$ See Tamar Ross, Expanding the Palace of Torah: Orthodoxy and Feminism (Waltham, MA: Brandeis University Press, 2004) 184-224.

${ }^{97}$ Benjamin D. Sommer, "Revelation at Sinai in the Hebrew Bible and in Jewish Theology," The Journal of Religion 79 (1999) 422-51. Sommer invokes the tradition attributed to Menahem Mendel of Rimanov (1745-1815), made famous by Scholem, in which revelation is described as consisting of only the aleph of the first word of the Decalogue. See also the remarks of Moshe Idel, Old Worlds, New Mirrors: On Jewish Mysticism and Twentieth-Century Thought (Philadelphia, PA: University of Pennsylvania Press, 2010) 121-24; and Zeev Harvey, "What did the Rymanover Really say about the Aleph of Anokhi?," Kabbalah 34 (2016) 297-314 (Hebrew); and Jerome Gellman, "Wellhausen and the Hasidim," Modern Judaism 26 (2006) 193-207.

${ }^{98}$ In a different vein, there is much to be gained from charting the ways in which the Hasidic sources challenge the ideas of Emmanuel Levinas, Eliezer Berkovits, or Joseph B. Soloveitchik; see Emmanuel Levinas, "Revelation in the Jewish Tradition," The Levinas Reader (ed. Sean Hand; Oxford: Blackwell Publishers Ltd, 1989) 190-210; Samuel Moyn, Origins of the Other: Emmanuel Levinas Between Revelation and Ethics (Ithaca, NY: Cornell University Press, 2005); Eliezer Berkovits, "The Encounter with the Divine," Essential Essays on Judaism (ed. David Hazony; Jerusalem: Shalem Press, 2002) 235-46; and Joseph B. Soloveitchik, Uviqqashtem mi-Sham (Jerusalem: World Zionist Organization, 1979) esp. 143-178.

99 See Gershom Scholem, "The Meaning of the Torah in Jewish Mysticism," (trans. Ralph Manheim; New York: Schocken Books, 1996) 35; Barbara Holdrege, Veda and Torah: Transcending the Textuality of Scripture (Albany: State University of New York Press, 1996) esp. 131-223; and William Graham, On the Written Word: Oral Aspects of Scripture in the History of Religion (Cambridge and New York: Cambridge University Press, 1987) esp. 1-77 and 117-54. 
explorations. For readers that are carefully attuned to the ideational core of their homiletics, these Hasidic texts may be interpreted as nurturing - and even demanding - a bold new approach to Sinai that does not rise or fall on the veracity of modern text-criticism or historical philology. By foregrounding these insights from centuries past, I have sought to articulate a constructive point as well: in charting a path forward, modern theologians would do well to train their eyes upon the creative literature of this early Hasidic school. 